\title{
Analysis of Constructivism Learning Theory
}

\author{
M. Givi Efgivia ${ }^{1 *}$, Adora Rinanda R.Y ${ }^{1}$, Suriyani ${ }^{2}$ Aang Hidayat $^{3}$, Irfan \\ Maulana $^{4}$, Anthon Budiarjo ${ }^{5}$
}

${ }^{1}$ Postgraduate Educational Technology, University of Ibnu Khaldun Bogor Indonesia

${ }^{2}$ YASMINA Foundation-Sekolah Kreativa, Bogor, Indonesia

${ }^{2}$ STKIP Muhammadiyah Bogor, Indonesia

${ }^{3}$ LKM Bogor, Indonesia

${ }^{4}$ SD Islam Ibnu Hajar Bogor, Indonesia

${ }^{5}$ MA Pesantren Ibnu Taimiyah Bogor, Indoneisa

*Corresponding author email: mgivi@uika-bogor.ac.id

\begin{abstract}
The constructivist revolution has deep roots in the history of education. This revolution relies heavily on the work of Piaget and Vygotsky as sources, both of which emphasize that cognitive change only occurs when the previous conception undergoes a disequilibration process because it emphasizes new information. Therefore, this study aims to 1) understand constructivism learning theory, 2) characteristics of constructivism learning theory, 3) understand the principles of constructivism learning theory, 4) determine the advantages and disadvantages of constructivism learning theory, 5) understand the stages of learning with approach to constructivism learning theory, 6) determine what learning models can apply constructivism learning theory, 7) describe examples of learning outside the network and in networks that implement constructivism learning theory, 8) understand about authentic assessment, 9) determine the types of learning the type of assessment in learning that implements constructivism learning theory, 10) understands the role of teachers and students in learning constructivism learning theory approaches, 11) describes the implementation of constructivism learning in Indonesia. The research method uses qualitative research methods (library research). Summary of Constructivistic theory emphasizes the principle of student-centered learning (student center). The conclusion from constructivist research theory is that teachers should not merely provide knowledge to students. Students must build knowledge in their own minds. Teachers just help provide the means and situations so that the students' knowledge construction process runs smoothly.
\end{abstract}

Keywords: Theory, Study, Constructivism, Revolution

\section{INTRODUCTION}

The constructivist revolution has deep roots in the history of education. This revolution relies heavily on the work of Piaget and Vygotsky as sources who both emphasize that cognitive change only occurs when the previous conception experiences an imbalance process because it emphasizes new information. Piaget and Vygotsky also emphasized the social nature of learning, and both suggested the use of mixed-ability learning groups to promote conceptual change (Piaget in Robert E. Slavin).

One of the most important principles of educational psychology is that teachers should not just impart knowledge to students. Students must construct knowledge in their own minds. Education is the ticket to the future. Tomorrow belongs to those who prepare themselves from today. The metacognitive constructivist model integrates the concepts of schemata, cognitive conflict, assimilation, accommodation, and equilibration in learning syntax as a representation of Piaget's personal constructivist character. Students who learn to use the metacognitive constructivist model will be guided to plan, monitor, and evaluate the achievement of learning objectives and strategies as a representation of the character of metacognitive strategies.

According to Ausubel, meaningful learning occurs if a process is associated with new information on relevant concepts contained in a person's cognitive structure, then if no effort is made to assimilate new understanding of relevant concepts that already exist in the cognitive structure, it will rote learning occurs. He also mentioned that the learning process consisted of two processes, namely the acceptance process and the discovery process (Dahar, Ratna Wilis). Thus, the activeness of students in finding concepts both alone and in group discussions makes the learning process meaningful. 


\section{METHOD}

The research method is using the type of qualitative research. This research process is carried out by researching and analyzing references from baboon books, supporting books, websites, YouTube, and group discussions related to the theme of constructivism learning theory.

\section{RESULT AND DISCUSSION}

The word constructivism etymologically has a constructive root which comes from the English word, constructive, which means "the one who builds (John M. Echols and Hassan Syadily, 2000 in http://repo.iain-tulungagung.ac.id). Whereas in the scientific dictionary it means "life of designing and building" (Widodo et al, 2002 in http://repo.iain-tulungagung.ac.id) and according to psychology, constructive means that it can be used for thoughts that produce new conclusions (James Drever, 1988 in http://repo.iain-tulungagung.ac.id).

Rusman (2013) says constructivism in learning is an approach in which students must individually find and transform complex information, check information with existing rules and revise it if necessary (Rusman, 2013 in http://repo.iaintulungagung.ac .id). While Wina (2005) Constructivism is the process of building or compiling new knowledge in the cognitive structure of students based on experience (Wina Sanjaya, 2005 in http://repo.iain-tulungagung.ac.id). So it can be concluded that constructivism learning theory is an educational theory that puts forward the improvement of the logical and conceptual development of learners. In constructivism there is the term "knowledge is constructed not transferred", so knowledge is to be built by the experience and knowledge of the learner and not only from the delivery or transfer from the teacher.

\subsection{Cognitive Constructive Learning}

\section{Theory}

According to Piaget, cognitive development is a genetic process, namely a process based on biological mechanisms in the form of the development of the nervous system. The stages referred to in Piaget's theory include 4 stages, namely: 1$)$ sensorimotor stage (0-2 years): children recognize the environment through motion and their senses (sensory) namely by sight, smell, hearing, touch. 2) operational stage (2-7 years): the emergence of motor skills and language. 3) concrete operations stage (7-11 years): children think logically about concrete events. The concrete operation stage is expressed by the development of a system of thought based on events that are directly experienced. 4) formal operating stage (11 years and over): children have the development of abstract reasoning. Piaget also argued that knowledge is not acquired passively by a person, but through action (Poedjiadi, 1999, in I.G.A. Lokita Purnamika Utami, 2016).

Jerome Bruner, another figure in cognitive constructive theory argues that the stages of cognitive development and the processes applied by individuals in solving problems faced are in accordance with their level of cognitive development and can move beyond their cognitive development through a learning process that emphasizes inquiry and discovery. The Learning by Doing learning approach is a cognitive constructive learning theory introduced by a cognitive learning theory token named John Dewey. He believes that learning must be relevant and theoretical. His views were very important in establishing the practice of progressive education.

From the above understanding, it can be understood that learning is an activity that takes place interactively between internal factors in the learner and external or environmental factors, resulting in behavioral changes. (Supratiknya, 2000, in I.G.A. Lokita Purnamika Utami, 2016).

\subsection{Social Constructive Learning Theory}

Social constructivism developed by Vigotsky emphasizes assisted-discovery learning (Ormord, 2007 in I.G.A. Lokita Purnamika Utami, 2016). This means that learning for children is carried out in interaction with the social and physical environment. Discovery in learning is easier to obtain in one's socio-cultural context (Poedjiadi, 1999, in I.G.A. Lokita Purnamika Utami, 2016). Sociocultural learning theory has its main emphasis on how a person learns with the help of others to understand something and solve the problems he faces. Within a zone of his own limitations, namely the Proximal Development Zone (ZPD) or the Proximal Development Zone and mediation. This theory emphasizes that human intelligence comes from society, environment and culture. This theory also asserts that individual cognitive acquisition occurs first through interpersonal (interaction with the social environment) intrapersonal (internalization that occurs within oneself).

\subsection{Characteristics of Constructivist Learning Theory}

Meanwhile, according to Winataputra in Wirdoyo, 2013 in Fatkhan Amirul Huda, 2017, the 
characteristics of constructivism learning theory include: 1) Developing alternative strategies to obtain and analyze information; 2) The possibility of multiple perspectives in the learning process; 3 ) The main role of students in the learning process; 4) The use of scaffolding in learning; 5) Educators are more like tutors, facilitators and mentors; and 5) Authentic learning activities and evaluations. From the explanation above, it can be concluded that the Constructivism model has characteristics in the learning process, namely student-centered, problem-solving, discovery processes, social interaction, and new knowledge or understanding.

\subsection{Principles of Constructivistic Learning Theory}

Broadly speaking, the principles of constructivism applied in teaching and learning are: a) Knowledge is built by the students themselves. b) Knowledge cannot be transferred from teacher to student, except only by the student's own activity to reason. c) Students actively construct continuously, so that there are always changes in scientific concepts. d) The teacher only helps provide suggestions and situations so that the construction process runs smoothly. e) Dealing with problems relevant to students. f) The structure of learning around the main concept of the importance of a question. $\mathrm{g}$ ) Seek and assess students' opinions. h) Adjusting the curriculum to respond to student perceptions (https://www.asiklearning.com, 2014).

\subsection{Strengths and Weaknesses of Constructivist Learning Theory}

\subsubsection{The Power of Constructivism} Learning Theory

According to Jasumayanti, 2013 in Fatkhan Amirul Huda, 2017 some of the strengths of the Constructivism approach in learning in schools are as follows: 1) Can familiarize students independently in solving problems; 2) Creating creativity for learning so as to create a more comfortable class atmosphere 3) comfortable and creative; 4) Cooperation is established and students are directly involved in carrying out activities; 5) Can make learning more meaningful because students are proud to find their own concepts being studied and students will feel proud of their findings; and 6) Train students to think critically and creatively.

\subsubsection{Weaknesses of Constructivism} Learning Theory

Analysis of the shortcomings of constructivist theory according to Afid Burhanuddin, 2014, among others: 1) Students create knowledge with their own ideas, therefore students' opinions differ from those of experts 2) This theory instills so that students build their own knowledge, this definitely requires long time. Especially for lazy students 3) Conditions in every school also affect student activity in building new knowledge and student activity.

\subsection{Learning Steps Procedure}

In constructivist theory there are several stages that must be known according to Sidik there are four stages, namely: 1) perception, the teacher should be able to encourage students to express initial knowledge about the concept to be discussed. 2) Exploration, the teacher prepares a discussion room for students directly. 3) Discussion and concept development, the teacher prepares a discussion room for students directly. 4) Development and application At this stage, the teacher should try to create a learning climate that allows students to apply their conceptual understanding. Meanwhile, according to Suprijono (2009) the constructivist stages are as follows: 1) Orientation, 2) Elicitation (exploring ideas) 3) Reconstruction of ideas 4) Application of ideas 5) Review. The learning models that can implement constructivism learning theory are: 1) Discovery Learning 2) Reception Learning 3) Assisted Learning 4) Active Learning 5) The Accelerated Learning 5) Quantum Learning 6) Contextual Teaching and Learning 7) Generative Learning.

\subsection{Authentic Assessment}

Authentic assessment is a significantly meaningful measurement of student learning outcomes for the domains of attitudes, skills, and knowledge. The term assessment is a synonym for assessment, measurement, testing, or evaluation. The term authentic is a synonym for genuine, real, valid, or reliable. As for the types of Authentic Assessment: a) performance appraisal, b) project appraisal, c) Portfolio appraisal, d) written appraisal. While the steps in authentic assessment, are: a) identify standards such as general goals (goals) b) Choose an authentic task c) identify criteria for tasks (tasks)

\subsection{The Role of Teachers and Students in Learning Theory of Learning Approach}

The Role of Teachers In constructivist learning, the role of teachers or educators is according to the opinion of C. Asri Budiningsih, 2005 in https://www.asiklearning.com/, 2014, including: a) helping the process of constructing knowledge by students run smoothly. b) helping students to form 
their own knowledge. c) understand the way of thinking or the perspective of students in learning. d) fostering independence by providing opportunities for decision-making and action. e) develop the ability to make decisions and act, by increasing students' knowledge and skills. f) provide a support system that facilitates learning so that students have optimal opportunities to practice. Apart from being a facilitator, more specifically the role of teachers in learning is as expert learners, as managers, and as mediators.

\subsection{The Role of Students in the Learning Process in Constructivistic Theory}

The role of students in the learning process in constructivist theory, including: a) Active constructors of knowledge formation through activities b) interpreting or compiling knowledge from concrete experiences, collaborative activities, and reflection and interpretation b) Students become the center of learning activities and teachers as facilitators. (N. Dariyanto Ferry)

In order for the role of students as "consumers" to be balanced with the role of 'producers', a teacher who acts as a facilitator is needed who is able to carry out educative teaching. The conclusion of the role of teachers and students according to constructivism is: the role of students as "consumers" of ideas has shifted towards the role of 'producers' of ideas. Meanwhile, the role of the teacher was shifted from the role of 'inhibiting the learning process' (learning destroyer) which often happens accidentally to the role of facilitator of the learning process (learning facilitator) (I Gede Astawan, 2016).

\subsection{Implementation of Constructivistic Learning in Indonesia}

In the constructivist view, students should no longer be passive recipients of the knowledge provided by the teacher and teachers should no longer be suppliers of knowledge and class managers. From this perspective, learning is a process of acquiring new knowledge, which is active and complex. It is the result of the active interaction of the main cognitive processes. It is also an active interaction between teacher and student, and students try to understand what is being taught by trying to adapt it to their own experience. The constructivist view also emphasizes generative learning, questioning or inquiry strategies. The constructivist view that emphasizes discovery, experimentation, and open problems has been successfully applied. Good teachers are those who teach for deep understanding: "They use students' ideas about science to guide lessons, provide experiences to test and challenge those ideas to help students achieve more sophisticated understanding. Such teachers are centered on students a place where group discussion, exploration and problem solving are common places.

\section{CONCLUSION}

Constructivism is one of the cornerstones of contextual teaching and learning (CTL) approaches. There are five important elements in a constructivist learning environment, namely: (1) paying attention to and utilizing students' prior knowledge, (2) meaningful learning experiences, (3) a conducive social environment, (4) encouragement so that students can be independent, and ( 5) there is an effort to introduce students to the scientific world. Constraints in the application of learning according to constructivism are: it is difficult to change the beliefs and habits of teachers, teachers are less interested and have difficulty managing constructivism-based learning activities, the teacher's assumption that the use of new methods or approaches in learning will take considerable time, an evaluation system that is still emphasizes the final grade, the magnitude of the teacher's teaching burden, students are accustomed to waiting for information from the teacher, and the existence of a negative culture in the student environment.

\section{REFERENCES}

[1]. Aunurrahman. 2009. Belajar dan Pembelajaran. Bandung: Alfa Beta.

[2]. Budiningsih, C. A. 2005. Belajar dan Pembelajaran. Jakarta: Rineka Cipta.

[3]. Sanjaya, Wina. 2008. Strategi Pembelajaran Berorientasi Standar Proses Pendidikan. Jakarta: Prenada Media Group.

[4]. Trianto, M.Pd. 2010. Mendesain Model Pembelajaran Inovatif-Progresif: Konsep, Landasan, dan Implementasinya Pada Kurikulum Tingkat Satuan Pendidikan (KTSP). Jakarta: Kencana.

[5]. Yulaelawati, E. 2004. Kurikulum dan Pembelajaran: Filosofi, Teori dan Aplikasi. Jakarta: Pakar Raya

[6]. H. Dadang Supardan, 2016. Teori dan Praktok Pendekatan Konstruktivisme dalam 
Pembelajaran. Edunomic Vol. 4. Bandung. UPI

[7]. Made Wena, Strategi Pembelajaran Inovatif Kontemporer, (Jakarta: Bumi Aksara,

[8]. 2013), hal.161

[9]. 69 Baharuddin dan Esa Nur Wahyuningsih, Teori Belajar dan Pembelajaran..., hal.18848

[10]. Kunandar, Guru profesional Implementasi Kurikulum Tingkat Satuan Pendidikan

[11]. (KTSP) dan sukses adalam Sertifikasi Guru, (Jakarta: Rajawali Press, 2008),

[12]. Rusman, Model-model Pemeblajaran, (Jakrta: PT Grafindo Persada,2013

[13]. Ngainun Naim, menjadi Guru yang Inspiratif memberdayakan dan Mengubah Jalan Hidup Siswa, (Yogyakarta: Pustaka Pelajar, 2011), hal.190 52

[14]. https://www.asikbelajar.com/peranan-guru, 2014 diakses pada 1 Juni 2021

[15]. http://www.membumikanpendidikan.com/20 14/11/peranan-guru-dalam-pembelajaranmenurut.html diakses pada 1 Juni 2021

[16]. I Gede Astawan, 2016 https://www.bernas.id/21283-peran-gurudan-siswa-dalam-pembelajaran-menurutpandangan-konstruktivisme.html diakses pada 1 Juni 2021

[17]. https://ferdonan.wordpress.com/teoribelajar-konstruktivistik/ diakses pada 1 Juni 2021.

[18]. Learning Theories Categories (https://www.learningtheories.com/constructivism.html)

[19]. http://repo.iain-tulungagung.ac.id diakses 30 Mei 2021

[20]. I.G.A. Lokita Purnamika Utami, 2016. Teori Konstruktivisme dan Teori Sosiokultural

[21]. https://ejournal.undiksha.ac.id

[22]. https:cdn-gbelajar.simpkb.id, 2021 Modul Bahan Belajar diakses 30 Mei 2021

[23]. https://fatkhan.web.id/pengertianpembelajaran-konstruktivisme/ diakses 30 Mei 2021

[24]. https://www.asikbelajar.com/ diakses 30 Mei 2021

[25]. Ika Pratiwi, 2013 dalam https://www.slideshare.net/ diakses 30 Mei 2021

[26]. https://afidburhanuddin.wordpress.com/2014 /05/06kekurangan-dan-kelebihan-teorikognitif-dan konstruktivistik/

[27]. https://youtu.be/kYU9UfkV_XI; Teori in Action : Constructivism
[28]. https://www.learning-

theories.com/constructivism.htmlhttps://iite. unesco.org/pics/publications/en/files/321473 $0 . p d f$

[29]. https://www.simplypsychology.org/Zone-ofProximal-Development.html 